\title{
Nias Language
}

National Cancer Institute

\section{Source}

National Cancer Institute. Nias Language. NCI Thesaurus. Code C154053.

An Austronesian language spoken on Nias Island and the Batu Islands of Indonesia. 